Hippodamia convergens Guer. Also found over the greater portion of the United States and in Canada.

Cytilus trivittatus Melsh. The United States north of Pennsylvania, westward to Idaho, common in Canada and in the higher Rocky Mountains of Colorado.

Athous cribratus Lec. Previously known from New Mexico (Taos Peak) and southern Colorado. A second specimen, differing in form of thorax, I refer with some doubt to the $q$ of the above, the sexes of Athous often being unlike.

Aphodius anthracinus Lec. Utah (American Fork Canon); Colorado (above Ouray, 9000-10000 ft.).

Leptura propinqua Bland. Western Canada, northern U. S. from Montana to the Pacific; Nevada, New Mexico, Arizona. Common in the mountains of Colorado.

Leptura nigrolineata Bland. Colorado (South Park, Leadville, Ouray and the adjacent mountains up to about I o, 000 feet).

Syneta carinata Mann. "Alaska, Idaho, Utah" (Horn). One in my collection is from the mountains of British Columbia, above the town of Donald.
Diabrotica tricincta Say. Colorado Springs and other points in Colorado, extends southward to Mexico. Not confined to the mountains.

Luperodes morrissonii Jac. "Southern California and Arizona." (Horn). Not quite typical, but according to the description very nearly so.

Galeruca externa Say. "Kansas, Utah, Nevada, Oregon, Washington, Idaho" (Horn). In my collection from Manitoba; California; Williams, Arizona; and several points in the mountains of Colorado (Leadville, Breckenridge, the Argentine Road, mountains above Ouray). I also have one from Glenora on the Stikine River in northern British Columbia.

Cantharis nuttalli Say. Winnipeg, Manitoba; Dakotas, Montana, various localities in Colorado; New Mexico.

Trichalophus alternatus Say. Not unfrequently met with in the mountains of Colorado. I have it from Breckenridge, Leadville, Red Cliff and the Argentine Pass road, also from Laramie, Wyoming.

Stephanocleonus cristatus Lec. Winnipeg, Manitoba; Leadville, Colorado.

\title{
NOTES ON MACROPSIS AND AGALLIA (JASSIDAE).
}

BY C. F. BAKER, ST. LOUIS, MO.

The article on these two genera in the November Psyche, calls for notice from me and I add further notes on the sub- ject with great willingness, especially as this case illustrates very well indeed the very detrimental effect of a common 
trouble among American workers, viz.: a lack of coöperation, be it generous or otherwise. I can only say that I am ready, as I have always been, to do anything in my power, regardless of all other considerations, to prevent such occurrences as this in connection with Macropsis and Agallia.

However, once in print, statements and descriptions cannot be withdrawn, inuch as we would like sometimes.

I drafted the descriptions of my new species of Agallia and Macropsis mentioned, some three years before they were printed and they were sent out for publication over two years before they finally appeared. I certainly was not aware of any paper having been published by Osborn and Ball on the subject, for none had been. And finally I did not hear of nor see the paper by Osborn and Ball until it was too late to withdraw my own.

If the types of Agallia mexicana fit exactly the description of modesta there can be no question of the synonymy. I followed my own "elaborate directions" and saw the female last ventral segment "slightly concave," though this would be no specific difference. The same is true of my species heydei and producta. Mr. Ball criticises me for describing from a single specimen, though on the same page he does likewise. Doubtless the "yellow saddle" is likewise a "result of accident or imperfect development," especially when we consider that the Agallias are quite variable in color. The name reticulata was long ago preoc- cupied in European literature. If this species is distinct from any of Uhler's it may be known as ballii. Mr. Ball should certainly state his grounds for reducing inconspicua, especially if it was based on an examination of the type.

I have no doubt whatever that peregrinans is a composite species, impossible of determination except through examination of the types. Any one of a half dozen North American and fifteen or twenty South American species would answer the description equally well. The types are credited to "Insulae Taiti et Oahu, California, Rio Janeiro; var. e Rio Janeiro." Osborn and Ball expressed doubt as to their own determination of it. Not having examined the types this doubt is a very laudable one. In any event the Sandwich Island form retains the name and lyrata cannot be reduced as a synonym of it. This is another "sad commentary on the accuracy" of Osborn and Ball's synonymical work.

Fowler's account of Macropsis had not been distributed when I sent out my paper, nor had Osborn and Ball's paper appeared. Mr. Ball here again mentions my "very meager" amount of material. I fail to see the point of this when the number of specimens averages as large as for many of his own species. The last ventral segment of female in alabamensis was described as three lobed, in apicalis this is said to be rounding or two lobed. As to the correctness of Mr. Ball's determination of misella (not "missella") I cannot say, not having 
seen the specimens. I can only say that the types of rufoscutellatus do not fit the description of misella - and this most decidedly. I cannot account for such a reference as this, and on so uncertain and ill-founded a basis.

Mr. Ball's guess concerning magnus as a form of californicus may possibly be correct. I guessed the same before describing them. However I had no proofs to bear me out, nor has Mr. Ball submitted any. If they did not represent species they certainly would varieties. Mr. Ball does not even allow them varietal standing, but in the same breath bases a "var. nov." on specimens of laeta "suffused with reddish." This reddish suffusion is a character not uncommon among various other Jassids. The reference of these species to humilis is wholly the most superficial guesswork. It is needless to say that the word " pronotum " in the fourth line of the description of magnus is a missprint for "elytra."

The species idioceroides does belong in the genus Macropsis as it is at present defined. Mr. Ball might just as well separate it as a new genus. It would be just as good a one as many others in the Jassidae.

\title{
COCCIDAE OF THE HARVARD BOTANICAL GARDENS.
}

\author{
BY GEO. B. KING, LAWRENCE, MASS.
}

The following is the result of two brief visits to the Harvard Botanical Gardens at Cambridge, Mass. The first was on July 15 of this year, in company with Mr. A. F. Perry. Just two hours' work was put in at this time. The next visit was by myself on August I3; about three hours were spent about the garden and greenhouses. Although we found a large number of coccids to inhabit this beautiful garden, we have by no means got all that really exist there. Other visits are contemplated and it should be said that a splendid opportunity presents itself here for students to study the life history of many interesting and injurious coccids. Several species are here cited for the first time, together with many new food plants, which adds considerably to our Massachusetts list.

I. Lecanium pruinosum Comst. MS., Coq. were found on Prunus domestica, var. Bradshawi, recorded here for the first time from Mass. The food plant is also new.

2. Lecanium quercitronis Fitch. on Xanthoxylum americanum a new food plant for this scale.

3. Lecanium longulum Dougl. on Monstera deliciosa, in the tropical greenhouse. This scale is of recent introduction, and new to Mass.; the food plant is also new.

4. Lecanium melaleucae Mask. on the same plant as the latter in the tropical greenhouse, and is of recent introduction 

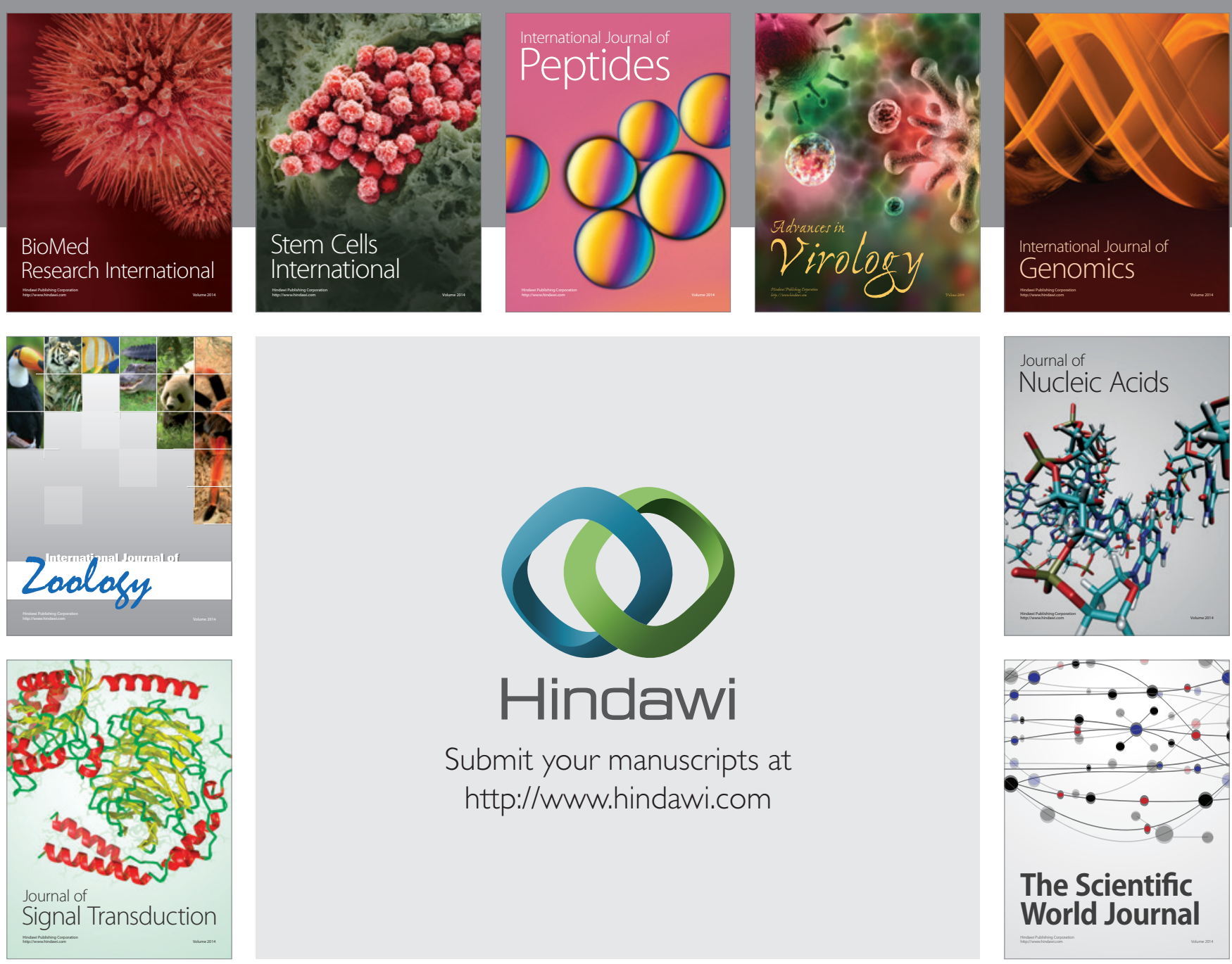

Submit your manuscripts at

http://www.hindawi.com
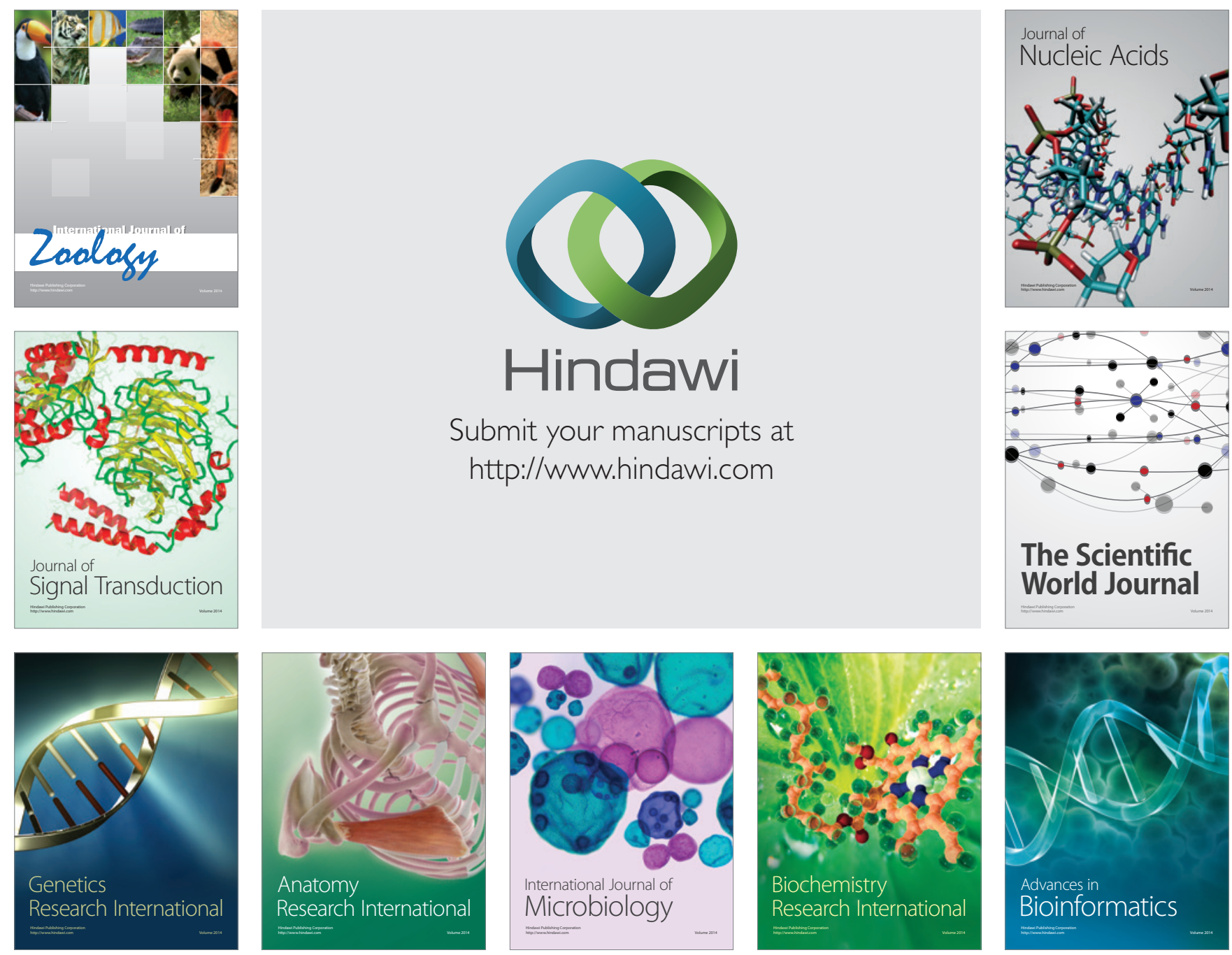

The Scientific World Journal
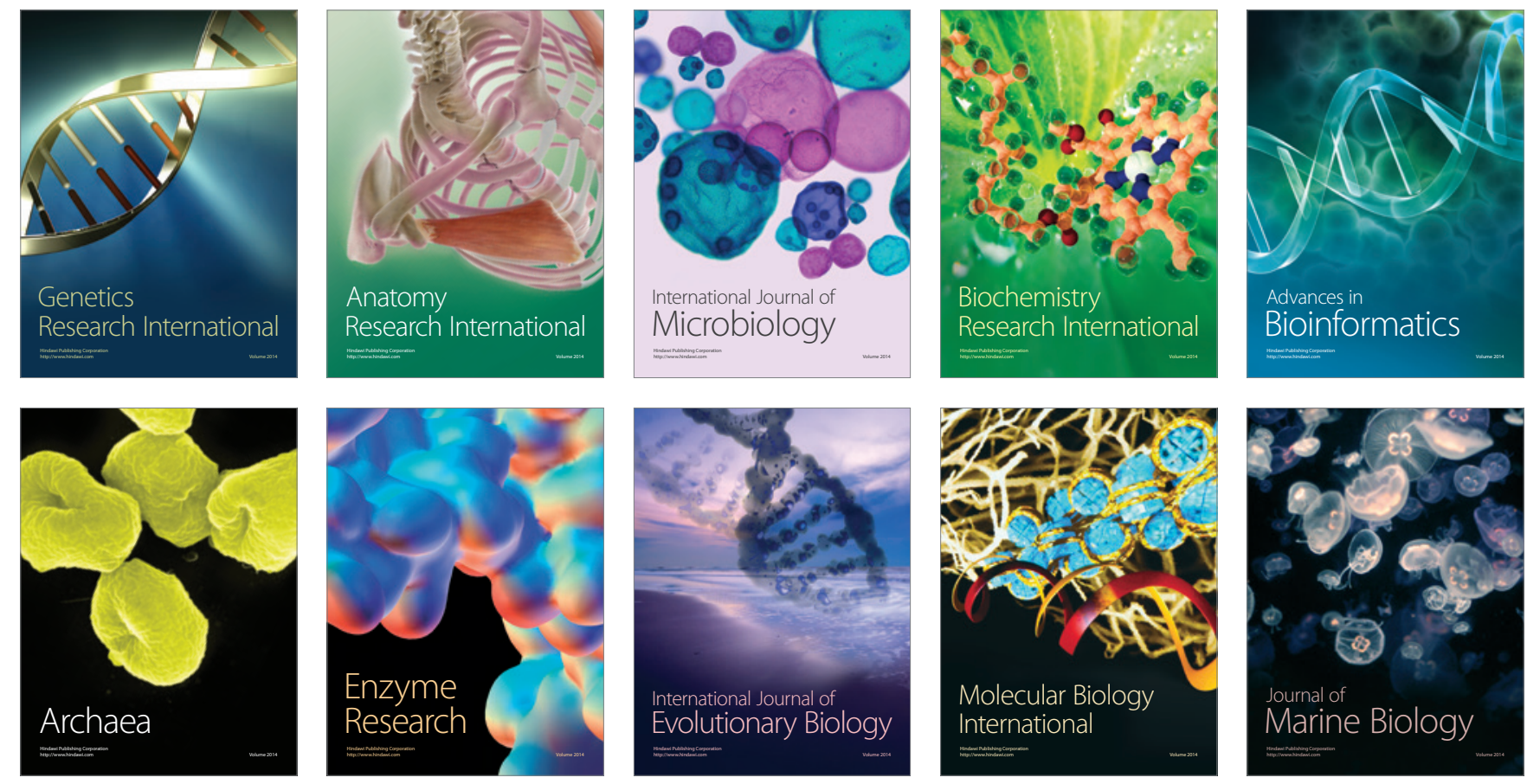